\title{
Parliamentary Control of "Other International Agreements" in the New Spanish Treaties and Other International Agreements Act (TOIAA)
}

\author{
Antonio FERNÁNDEZ TOMÁs*
}

\begin{abstract}
The new Spanish Act on Treaties and Other International Agreements (TOIAA) regulates two figures of the Spanish praxis that do not exist in the 1969 Vienna Convention and is not usually regulated in national domestic law either. These other international agreements (OIA) follow this classification: Administrative International Agreements (Executive International Agreements) and Non-normative International Agreements (Memoranda of Understanding). Only if administrative agreements may be qualified as "international" (AIA) fall within the scope of the TOIAA and must be published in the Spanish Official Gazette (BOE). The regulation of Non-Normative International Agreements (NNIA) tries to establish a minimum preventive control of the Government over the international activities of other entities, especially of Regions, which try to use them as a foreign projection of their powers. But Parliamentary control of both figures is deficient. This is notorious in the case of AIA, because the Government has recently used this figure to circumvent Parliamentary control of agreements regulating the European bailout of Spanish banks. That is hardly compatible with the provisions of our Constitution.
\end{abstract}

Keywords: Law of treaties - administrative international agreements - memorandum of understanding

\section{INTRODUCTION}

The Vienna Convention on the Law of Treaties was adopted at Vienna on $22^{\text {nd }}$ of May 1969 and opened for signature the following day by the UN Conference on the Law of Treaties. Spain formally accepted the treaty three years later through accession on May $16^{\text {th }} 1972$. Taking into consideration its late entry into force ${ }^{\mathrm{I}}$, the Spanish Government operating in the last years of General Franco's regime enacted the Decree 80I/1972 as a means to introduce the provisions of the Convention into Spanish domestic Law. When the democratic Constitution was proclaimed on December 6th 1978, some parts of the aforementioned Decree did not comply with the new political reality, but others remained technically impeccable and are still enforced today ${ }^{2}$. Nevertheless, the convenience of a better adjustment of both constitutional provisions and the domestic law of treaties justified a preliminary draft in $1985^{3}$ followed by several further $\mathrm{drafts}^{4}$, none of which were in the end sent to the Parliament.

* Professor of Public International Law, University of Castilla-La Mancha, Spain. The author has collaborated with the Socialist Parliamentary Group (SPG) regarding the amendments to the TOIAA. However, opinions expressed in this paper remain exclusively personal. This contribution has been made it within the framework of the research project DER 20I235049, funded by The Spanish Ministry of Economy and Competitiveness. English translation: Miguel Álvarez Ortega, University of Seville.

$27^{\text {th }}$ January 1980.

The drafter of the Decree was Professor Julio D. González Campos who later became a Constitutional Court Magistrate. Ms Miguélez Pariente, pertaining to the Popular Parliamentary Group admitted during the parliamentary discussion of the draft of the TOIAA that "[the Decree] could not have been poorly designed because it has enabled the signature of almost 30.000 treaties since 1972”. Diario de Sesiones del Congreso de los Diputados (Record of Parliamentary Proceedings), Comisiones, $\mathrm{n}^{\mathrm{o}} 587, \mathrm{II}^{\text {th }}$ june 2014 , p. 8.

3 It was a version of the preliminary draft of the act regulating the management of the State's activity regarding International Treaties, presented by the Council of State Working Group in charge of such matter on $9^{\text {th }}$ April 1985 . Text 
Successive democratic governments (UCD, PSOE and PP) deemed normative dissonances to be a minor issue and preferred to update the Decree 80I/72 by means of Administrative Circulars 5 . That was especially the case after the ruling of the Constitutional Court (Order $114 / 199 \mathrm{I}^{6}$ ) validating the common practice of concluding International Treaties using simplified means of expressing consent lacking Royal Assent, despite the provisions contained in Article 63.2 of the Constitution.

The remaining conventions regarding the codification on the law of treaties have had little to no impact on the Spanish Act ${ }^{7}$. The Vienna Convention of 1986 on the Law of Treaties between States and International Organizations or between International Organizations has not come into force yet, though Spain accessed to it on July $24^{\text {th }}$ I990. The Explanatory Memorandum of the TOIAA contains references to developments made by International Organizations with capacity to conclude International Treaties. But if those mentions concern to the treaties celebrated by the EU and member states, the primary though not exclusive reference is EU Law. Moreover, Spain concludes not only treatises, but also other international agreements with international organizations different than the EU. In any case, allusions to the Vienna Convention in this paper are to be understood merely as reference to the 1969 Vienna Convention on the Law of Treaties between States.

\section{PARLIAMENTARY PROCEDURE AND SCOPE OF THE NEW ACT}

Breaking the prudent tendency showed by the five previous democratic Governments, President Rajoy's Government decided to draft a new act on International Treaties. It is necessary to

reproduced in VV.AA. La celebración de tratados internacionales por España (The Conclusion of International Treaties in Spain) (Ministerio de Asuntos Exteriores, Madrid, 1990, Annex).

4 There was an unpublished draft dating from $20^{\text {th }}$ November 1990. C. Gutiérrez Espada refers to two preliminary drafts dating from 1989 and 1990 (see Derecho Internacional Público (Trotta, Madrid, 1995), at 378, footnote 20). Reference to "at least four serious attempts to elaborate such a preliminary draft (1979, 1985, 1999 y 2011)" may be found in Memoria del análisis de impacto normativo del anteproyecto de ley de tratados y otros acuerdos internacionales (Ministry Report), Ministerio de Asuntos Exteriores, 25th October 20I3, at 8.

5 Ministry of Foreign Affairs Circular $\mathrm{n}^{\circ}$ 2.951, July ist 1981 (Published in La celebración de tratados internacionales por España, supra n. 3, Annexes); Issued Order (Orden Comunicada) 3.171, February 17th 1992, establishing the rules for the processing of international treaties (Official Gazette of the Ministry of Foreign Affairs, $\mathrm{n}^{\circ}$ 592, February 1992); Issued Order of the Ministry of Foreign Affairs, July $\mathrm{I}^{\text {th }}$ 20IO, regulating the processing of non-normative agreements [MOU,s] (Circular 3.286, July $19^{\text {th }}$ 2010). [Unpublished]. We also need to consider Instruction of Service $\mathrm{n}^{\circ} 74$, Technical General Secretary of the Ministry of Foreign Affairs, July $28^{\text {th }} 2009$, regulating the procedure to apply for full powers; Instruction of Service $\mathrm{n}^{\circ} 75$, Technical General Secretary of the Ministry of Foreign Affairs, July $28^{\text {th }} 2009$, regulating ad referendum signature and provisional application of international agreements; Instruction of Service $\mathrm{n}^{\circ}$ 97, Technical General Secretary of the Ministry of Foreign Affairs, November $3^{\text {rd }} 2009$, regulating the processing of dossiers for the Council of Ministers according to Circular Order $\mathrm{n}^{\circ}$ 3.171, March 14 th 1992, regulating the processing of international treaties, and, finally, Circular Order $\mathrm{n}^{\mathrm{o}}$ 2.882, Technical General Secretary of the Ministry of Foreign Affairs, November $28^{\mathrm{t}^{\text {th }}}$ 1977, regulating the use if the Spanish language in treaties signed or ratified by Spain.

6 Constitutional Court Order II4/1991, April II ${ }^{\text {th }}$ I99I.

7 The 1978 Vienna Convention of Succession of States in respect of treaties came into force on November $6^{\text {th }}$ 1996, but Spain never ratified it. Article 34.I.c of the TOIAA's Project, as it was initially sent to the Congress, provided that "in conformity with general rules of International Law (...) directives will be established in order to regulate: "c) the new scope of an international treaty should there be any territorial changes affecting another State party". But the text attached to the Congress drafting report instead read c) "the territorial scope of the treaty", thus excluding succession of States from the Act's scope. 
contextualize this decision within his broader legislative production. In the international context, after sending to Parliament a draft of the Act on Foreign Action and External Service, passed as Act $2 / 2014$ on March $25^{\text {th }} 2014^{8}$, he proceeded with this Act on international treaties and other international agreements. Remission to Parliament of the draft was approved on October $25^{\text {th }} 2013^{9}$, and two complete amendments referring the draft back to the Government were submitted by the Basque Parliamentary Group and the Plural Left Wing Parliamentary Group on December $3^{\text {rd }} 2013$. The Congress rejected those amendments in a plenary session on December $12^{\text {th }} 2013^{10}$. A total of 163 amendments ${ }^{\text {II }}$ were examined before the debate, each with a different outcome. 52 of them were accepted. Interestingly, though, most had been presented by the Plural Left Wing Parliamentary Group $^{12}$ and deemed technically correct by the Government representatives. On the other hand, the majority of proposals presented by the Socialist Parliamentary Group (SPG) were rejected, as they were alleged to be politically incorrect ${ }^{\mathrm{t} 3}$. Once the Congress drafting committee's report was issued, SPG tried to present two compromise amendments the day before the debate in a desperate attempt to achieve some consensus. Nevertheless, they were all rejected by the Congress Commission of Foreign Affairs ${ }^{\mathrm{I}}$, which resulted in SPG voting against the project.

On September 2014 the Basque Parliamentary Group decided to present a veto proposal while the project was still being considered by the Senate, adding on to the 194 amendments presented by other Parliamentary groups ${ }^{15}$. Most of them reiterated what had already been defended in Congress. PPG and SPG agreement some amendments on technical questions included it into Senate drafting committee's report, Senate Commission of Foreign Affairs accepted it and Draft is voted, been rejected the rest, in a plenary session on October 29. Returned to the Congress, Draft is definitively approved on November 25.

The official publication of the Treaties and Other International Agreements Act (TOIAA) ${ }^{16}$ marks the conclusion of the internal legislative procedure, but does not exempt us from undertaking deeper reflection about the need of the new act and its adequacy to fulfil its goals. If the Constitution and Decree $80 \mathrm{I} / \mathrm{1972}$ were able to coexist for 36 years, why should the Government change their mind now? Isn't the combination of the aforementioned Decree with the Vienna Convention, incorporated

\footnotetext{
8 Official Gazette (BOE), $\mathrm{n}^{\mathrm{o}} 74$, March 26th 2014.

9 The draft was published on November $5^{\text {th }} 2013$ in the Official Gazette of the Congress (BOCG).

ro Record of Parliamentary Proceedings, Pleno y Diputación Permanente, $\mathrm{n}^{\mathrm{o}} 165$, December $12^{\text {th }} 2013$, p. 18.

II Official Gazette of the Congress (BOCG), Congress, Serie A, $n^{\circ} 72-2$, February $7^{\text {th }} 2014$, at $\mathrm{I}-83$.

I2 According to the spokesman of the SPG, Mr. López Garrido, "the Popular Group has no accepted hardly any of the amendments we have proposed, preferring to establish agreements with other Parliamentary groups. In this case, we could say that bi-partisanship, not sure if partial or total, has been performed with Pluralistic Left; in any case, the Socialist Group has not been part of it at all”. Record of Parliamentary Proceedings, Comisiones, $\mathrm{n}^{\mathrm{o}} 587$, June $\mathrm{II}^{\text {th }}$ 2014, at 5 .

r3 See the heated debate between Mrs. Miguélez Pariente and Mr. López Garrido in Record of Parliamentary Proceedings, Comisiones, $\mathrm{n}^{\mathrm{o}} 587$, June $\mathrm{II}^{\text {th }}$ 20I4, at 9 . "It is true that certain amendments have been accepted, but it is easy to understand why listening to your speech. United Left (Izquierda Unida) presented many technical amendments that have been accepted due to its improvement on the text, whereas your amendments have had a much political character and that is why many of them could not be accepted".

I4 Record of Parliamentary Proceedings, Comisiones, $\mathrm{n}^{\circ} 587$, June IIth 20I4, at I-I2.

is BOCG, Senate, X legislature, I5-09-2014, p. 52 and ff. See the texts available electronically at <http://www.senado.es/web/actividadparlamentaria/iniciativas/detalleiniciativa/index.html legis $=$ Io\&idI $=62 \mathrm{I} \& \mathrm{id} 2=000078>$.

16 Official Gazette (BOE), 28 November 2014.
} 
into the Spanish domestic law after its publication in the Official Gazette (BOE) ${ }^{17}$ enough? Was it really necessary to substitute the Decree and the Administrative Circulars with the new Act in order to enable a better internal handling of treaties?

The Preamble to the TOIAA mentions three reasons to justify the need for a new Act. Firstly, the Decree is considered obsolete ${ }^{18}$ and inadequate to the exigencies of the Spanish Constitution. That is certainly the case, but we could find the very same situation since 1978 when the Spanish Constitution was proclaimed. Secondly, contemporary developments of Public International Law are characterised by a "new phenomena" such as the "multiplication of international organizations with a capacity to conclude international agreements" ${ }^{19}$, the EU being the most notorious example. Though this is also certainly the case, Spain has been a part of the EU since January 1986. Thirdly, the Spanish international legal praxis currently accounts for a more extensive reality that the one contemplated by Decree 80I/1972 and the Vienna Convention, because it covers not only the conclusion of treaties, but also the conclusion of other international agreements ${ }^{20}$. This third reason might have been decisive, as odd as it may seem, in the effort to promote a new Treaties Act.

However, as a consequence, the end result is a bit absurd for to the following reasons. Firstly, a complete Treaties Act is drafted in order to regulate instruments that are not treaties, but rather other international agreements (OIA). Secondly, this domestic Act whose main aim seems to be the regulation of this field, does not account for all other international agreements. This is because only International Administrative Agreements (IAA) are regulated, while Executive Agreements (EA) or Administrative Agreements (AA) that are not regulated by International Law, but by the domestic Law of one of the parties (Article I combined with Art 2.b. in fine) ${ }^{21}$ are excluded. Thirdly, though in opposition to the criterion just mentioned, Memoranda of understanding (MOU) are explicitly included, despite the fact that they are not regulated by International Law (Article 2.c in fine ${ }^{22}$ ).

So, what is the common base for the three cases accounted for in the Act? Is it the International character of the agreements? And how is that internationality to be determined in the Legal realm if not by virtue of International Law itself being applicable? Therefore, if International Law does not regulate one of the three basic categories contemplated (MOU) and regulates just partially another of the three (Administrative Agreements [AA] or Executive Agreements [EA]), is an International Treaties Act the best logical option to regulate those other agreements that occur in our praxis? Would it not have been better to leave Decree $801 / 72$ and the Circulars the way they were and create a new Act to regulate all of the other agreements that do not constitute International Treaties taking place in the Spanish praxis? From my point of view, the second option would have been more appropriate.

17 Official Gazette, June $13^{\text {th }} 1980$.

I8 TOIAA, Explanatory Memorandum, I.

19 TOIAA, Explanatory Memorandum, II.

20 Ibid.

2t Article I: "This act aims at regulating the conclusion of international treaties, administrative international agreements and non-non normative international, agreements defined in Article 2, by Spain". Article 2.b. in fine: "an [executive] agreement concluded by the same organs, agencies or entities is not an administrative international agreement when they are ruled by a domestic legal system" (emphasis added).

${ }_{22}$ "And it does not generate international obligations, neither is it ruled by International Law". 


\section{OTHER INTERNATIONAL AGREEMENTS (OIA)}

A true pioneer in contemporary comparative Law ${ }^{23}$, the Spanish Act accounts for two other types of International Agreements (OIA) besides International Treaties: some Executive Agreements (EA), named Administrative International Agreements (AIA) and Memoranda of understanding (MOU), named Non-Normative International Agreements (NNIA). Both are qualified as "international" in the Preamble and throughout the articles of the Act.

\section{(I) Administrative international agreements (AIA)}

The new Act (Article 2.b) establishes seven elements in order to determine whether a legal act is an AIA: I. They have an "international character", but they "do not constitute a Treaty" (they are defined by exclusion, so the intention of the parties is crucial in order to identify its legal nature); 2. "They are concluded by organs, agencies or entities of a subject under International Law" (One organ for each party, of course. They may also be concluded with International Organizations); 3. That organ must be "competent ratione materiae", which is obvious, but one has to interpret (through omission) that this organ does not need to possess special powers in international relations affairs, which truly defines this kind of instrument; 4. The conclusion of an executive agreement "is provided in the treaty being executed or specified", which is usually called a framework agreement [umbrella agreement]; 5. Its "normal content possesses a technical nature", which is an unnecessary provision that leaves the door open for other administrative agreements to posses a nature "other" than technical; 6. "Whatever their particular designation"; this is a generic precision in the Law of Treaties ${ }^{24}$ that has become relevant in the context of recent Spanish praxis (see last section of this article below); 7. "And that is regulated by International Law", this last criterion being decisive in order to include or exclude an AA in TOIAA scope.

In my opinion, the new Act unnecessarily subdivides AA into two categories according to whether or not the agreement is "regulated by International Law". The consequence is that the former would fall within the scope of the TOIAA (Article I combined with Article 2.b), while the latter would not. It is my belief that this is not the best possible approach, since it excludes widely used instruments -especially in areas like Social Security ${ }^{25}$, Scientific and Technical Cooperation and possibly taxation ${ }^{26}$ - such as the type

${ }_{23}$ As stated in the Ministry Report (supra n. 4, at 19-20), adding that the Netherlands Act does not cover AIA as a category different from treaties and, regarding NNIA, it reads "some States, such as Germany or United Kingdom, do cover them in their regulation of the processing of international agreements, while some other country, like France, explicitly excludes them".

24 See 1969 Vienna Convention, Article 2.I.a).

25 There are numerous agreements of this type between Spain and other Latin American countries like Paraguay, Venezuela, Chile, Ecuador, Mexico, Peru, El Salvador, Colombia (and also with Morocco), published in the Official Gazette (BOE). Since official publication is not compulsory, it is possible that there may be some other unpublished agreements. See A. Fernández Tomás, "La válida celebración y la incorporación de los tratados en la jurisprudencia constitucional española", in Hacia un nuevo orden internacional y europeo. Estudios en bomenaje al profesor Don Manuel Díez de Velasco, Tecnos, Madrid, 1993, at 352.

${ }^{26}$ In any case, additional provision 5 of the TOIAA (entitled "implementing acts of international treaties aimed at avoiding double taxation and transfer price agreements") excludes from the scope of the Act "implementing acts of international treaties or covenants in order to avoid double taxation, particularly agreed solutions for conflict-resolution in 
of executive agreements that refer to a domestic Legal System instead of to Public International Law. In Spain, it is also the case that a framework agreement sometimes provides the constitution of a specific organ established by the parties with an executive aim. This would be a Joint Commission endowed with enough powers to generate new executive acts by means of successive resolutions ${ }^{27}$ that may be regarded as another expression of an executive agreement between the parties.

On the other hand, the concept of AIA in the context of the TOIAA does not improve on the preexisting notion AIA stated in 1990 by both the International Legal Advisory (ILA) of the Ministry of Foreign Affairs and the Council of State. The latter ${ }^{28}$ rightly defended regarding executive agreements, that "not every executive act of a Treaty adopted by mutual agreement by the organs of the public administrations of the contracting parties is an international agreement" (...), [since] "there are many Treaties whose execution is not unilaterally undertaken by each of the contracting States, but it is rather entrusted to the constant collaboration of the organs of the public administration of those States competent in the area regulated by the Treaty. It may be said that in these cases, conventions, concluded after a negotiation and an agreement, lead to an on-going process of negotiation and agreement during their execution that already takes place at an administrative level that is, it occurs between organs that lack of representation to bind the State by means of International Treaties. These agreements between administrative organs of the Parties that are competent ratione materiae may be regulated in the corresponding main Treaty that will usually designate by name the contracting organs and establish the future content of the agreement (emphasis added) ${ }^{29}$ ".

We are therefore facing agreements executing a previous Treaty - the framework agreement [umbrella agreement] - even if those concluding them are organs lacking legal capacity in the area of international relations. Thus, the Note of the ILA of the Ministry of Foreign Affairs from May ${ }^{\text {th }}{ }^{\text {th }}$ I990 indicates the characteristic features of this type of agreements, i.e., the existence of a formal coverage (the possibility of a executive agreement needs to be explicitly provided in the Framework Treaty) and a material coverage (the Framework Treaty must contain a subject susceptible of further development or execution by means of an executive agreement). And, to a certain extent, we could say that between the framework agreement and the executive agreement there is a similar relation to that which exists between an Act, and its implementing and executing Regulation, respecting the principle of legal reservation if applicable ${ }^{30}$.

the implementation of double tax treaties. Nor agreements signed between taxation administrations for assessment of transactions performed between related persons or companies". That implies that administrative agreements regulating these two subjects fall without the scope of the Act even if they are international.

${ }_{27}$ See, for all, Basic Agreement on Technical \& Scientific Cooperation with the Republic of Colombia, June $27^{\text {th }} 1970$ (Official Gazette, March $7^{\text {th }}$ 1988I), whose Joint Committee (Article 6) will pursue, among other goals, "b) the promotion, consideration and approval of programmes and projects of technical cooperation" (emphasis added).

${ }_{28}$ In Spain the Council of State is an exclusively consultative organ provided in the Constitution and regulated by an Organic Act (Act 3/30, April 22 ${ }^{\text {nd }}$, LOCE), that must submit non-binding reports to the Government in the processing of "all international treaties or covenants regarding the need of Parliamentary authorization" (Article 22.I LOCE). This organ is absolutely different from the Constitutional Court (CC). Our organizational chart is, thus, different from the French one on this matter.

29 Council of State. Opinion of Plenary $n^{\circ} 55.253$, November $22^{\text {nd }} 1990$.

30 Constitutional Court Order II4/I99I, F.J. 4: "It is obvious that Article 5 of the European Convention on Extradition, in its original wording prior to the Second Protocol, had expressly provided the possibility that the Parties include within its 
Luckily, even if the definition in Article 2.b is not as accurate as desirable ${ }^{31}$, Article 38 of the TOIAA ${ }^{32}$ properly completes the notion establishing the requisites of an AIA in accordance with the guidelines stated by the State Council. Thus, in the first place, "the organs, agencies and entities of the Public Administration may conclude international administrative agreements executing and developing an International Treaty should it be provided in the Treaty itself" (38.I, emphasis added). "Administrative international agreements may only be concluded by authorities designated in the very International Treaty or, failing that, by the holders of the organs, agencies and entities of the Public Administration possessing competence ratione materiae" (38.2, emphasis added)). And finally, the most important provision states that "Administrative International Agreements must respect the content of the Treaty providing them with coverage as well as the limits for their conclusion eventually established in the aforementioned Treaty" (38.3, emphasis added).

This regulation entails that the Framework Agreement serves as a validity criterion for the AIA. In other words, it implies that the "valid conclusion" of an administrative agreement will depend upon its conformity with the Framework Agreement. This is why one of the amendments presented by the SPG and accepted into parliamentary procedure ${ }^{33}$ refers precisely to this issue. If Art 96.I of our Constitution establishes that the "valid conclusion" of a Treaty is a necessary condition for its reception and incorporation into our Legal System, why not state a similar provision regarding administrative agreements that are also to be incorporated after their publication in the Official Gazette (BOE)? After the acceptance of the amendment by the Congress Drafting Committee, the condition was established in Article 43.4 which becomes Article 42.4 after the debate in the Foreign Affairs Commission of the Congress and finally, Art. 4I.4. We may assume that this precept will enable the eventual challenge [ineffectiveness claim] of those administrative agreements not "validly concluded" due to lack of conformity with the Framework Agreement.

In addition, the definition contained in Article 2.b TOIAA is unnecessarily over-comprehensive, since there was no need to make a reference to the content of AIA, which may regulate any matter (military and defence cooperation, education and cultural cooperation, economic and technical cooperation, headquarters agreements with international agencies ${ }^{34}$, trans-boundary cooperation).

If the regulation of AIA by International Law is the determining criterion for its inclusion within the scope of the new Act, we may ask which rules of International Law may govern administrative

scope tax criminal offences, under the terms provided by the same precept. The fact that the reference needs to be understood as an allusion to agreements concluded between administrative authorities, having their behaviour and provisions strictly limited and regulated by the Covenant, comfortably meets the principle of legal reserved, as it has been established in Constitutional Court Ruling 42/1987" (F.J.2), (emphasis added).

${ }_{31}$ To claim that the conclusion of administrative "is provided" (Article 2.b TOIAA) in the treaty it is developing is not saying much, considering the former Opinion of the Council of State.

32 Article 40 of the initial draft, turned into 39 after the debate in the Committee on Foreign Affairs in the Congress, and finally, Art. 38 .

33 Amendment $\mathrm{n}^{\circ}$ 138: "Validly concluded administrative international agreements will be part of the domestic Law once published in the Official Gazette (BOE)". Official Gazette of the Congress (BOCG), Congreso, X Legislatura, Serie A, $\mathrm{n}^{\circ} 72-2$, February $17^{\text {th }} 2014$, at 64 . The amendment was accepted by the Congress drafting committee that submitted the document to the Foreign Affairs Committee (Official Gazette of the Congress (BOCG), Legislatura, Serie A: proyectos de ley, 7 de mayo de 20I4, $n^{\circ}$ 72-3, at I. http://www.congreso.es/public_oficiales/Lio/CONG/BOCG/A/BOCG-IO-A-72-3.PDF.

34 These subjects are mentioned as examples in Ministry Report (supra n. 4, at 19). 
agreements? Considering that the Vienna Convention does not cover administrative agreements, it seems difficult to defend the generation of new customary rules for administrative agreements through a generalised and uniform practice that has arisen since it came into force. We need to bear in mind that every State is regarded as a "concerned State" in respect of treaties and other international agreements and that no opinio iuris has been generated. So, lacking specific customary rules about AIA, Public International Law rules that may be applicable through analogy are those regulating international treaties, which, however, do not even mention them.

Which other International Law norms may we consider for the "ruling" of an AIA? Those regulate international responsibility and dispute settlement. If we consider that an administrative international agreement gives rise to true international legal obligations whose breech constitutes an internationally wrongful act. Even if that is the case, since it is the theoretical element that differentiates this category before Memoranda of Understanding, it is not very practical to invoke international responsibility of a State due to the breech of such an agreement unless there is a specific agency in charge of dispute settlement established in the framework agreement. This could happen in the area of transboundary cooperation ${ }^{35}$ between Spain and France, on the one hand, and Spain and Portugal on the other, where International Law rules and principles on shared spaces and resources within the framework of the Policy of Good Neighbourliness may be applied. It could also take place in other areas such as military cooperation in security and defence. Here a bilateral or multilateral partnership generates a complex web of acts of different rank and nature which are capable of creating a special regime based upon Public International Law, in which, for example, privileges, immunities and other jurisdictional exemptions are either contemplated in successive instruments or identified through referral.

But, the fact that there is a wide range of administrative agreements - may they be concluded with an agency pertaining to another State or to an international organization ${ }^{36}$ - whose implementation may require the application of certain rules of International Law does not justify leaving the rest of the agreements outside the scope of the TOIAA ${ }^{37}$. Yet, the final paragraph in Article 2.b clearly states that "it does not constitute an administrative international agreement (...) if it is ruled by domestic Law", thus excluding it from the scope of the Act. This Article implies that the triple obligation in Title III TOIAA does not apply to the simple AA [not AIA]. So, they don't need a report of the International Legal Advisory of the Ministry of Foreign Affairs (Art. 39) in order to have their nature

35 Reference is made in Opinion $n^{\circ} 808 / 2013$, Plenary of the Council of State, October $3^{\text {rd }}, 2013$, at 24.

36 For example, the agreement on tax exemptions for personnel working at NATO Headquarters by means of an Exchange of Letters (April $\mathrm{I}^{\text {th }}$ and $\mathrm{I}^{8^{\text {th }}}$ 2000) between SACEUR (NATO) and JEMAD (Spain). The agreement produced a lawsuit resolved by the Spanish Supreme Court (Ruling of the Supreme Court, Jun 2oth 20II). A. Pastor Palomar, "Acuerdos internacionales de España que incluyen la concesión de exenciones fiscales", in S. Torres Bernárdez et al., El Derecho internacional en el mundo multipolar del siglo XXI. Obra homenaje al profesor L. I. Sánchez Rodríguez (Iprolex, Madrid, 20I3), at I86, points that "The SC seems to qualify the aforementioned Exchange of Letters as an administrative agreement, since it is an agreement developing a prior framework agreement, concluded by organs lacking international representation".

${ }_{37}$ That is why the SPG proposed the elimination of the phrase "and that is ruled by International Law" and the final remark "An agreement signed by the same organs, agencies and entities is not an administrative international agreement if it is ruled by domestic law". See their Amendment no Io8, Official Gazette of the Congress (BOCG), Congreso, Serie A, $\mathrm{n}^{\circ} 7^{7-}$ 2, February $17^{\text {th }} 2014$, at 53 . The amendment was rejected. 
checked (and thus detect "hidden treaties" ${ }^{38}$ ); the Council of Ministries don't has to be informed (Art. 40) and they don't be published in the Official Gazette (BOE) (Art. 4I). And that is far from desirable. If they were included within the scope, a better parliamentary and judicial control ${ }^{39}$ of the external action of the Government would be granted, reinforcing citizen's rights according to the principles of the rule of law.

\section{(2) Non-normative International Agreements (NNIA).}

\section{(a) Academic reflections}

From the mid 70 s on, scholars have highlighted the existence of intentionally ambiguous instruments whose nature is more political than legal, such as joint declarations, letters of intent and collaboration communiqués. Some ${ }^{40}$ have identified the most relevant feature of this sort of non-conventional concerted acts (gentlemen's agreements ${ }^{4 \mathrm{r}}$, memoranda of understanding) that create a non-binding commitment that "despite that, possesses a certain expectation of fulfilment" ${ }^{2}$. Their existence has been acknowledged in the most diverse International spheres of - "as disparate as Helsinki Final Act or town twinning arrangements 43 "- in which the flexibility of an instrument capable of generating political agreements was preferable to the rigidity of legal obligations ${ }^{44}$, etc.

This type of agreement presents a twofold problem. The first issue refers to its characterisation, since it is necessary to distinguish if is a treaty or not. The second issue relates to its potential effectiveness between the contracting parties. The first problem must be fundamentally resolved taking into account the intention of the parties ${ }^{45}$, there is no reason why drafting tips ${ }^{46}$, guidelines ${ }^{47}$ or other complementary

$3^{8}$ J. González Vega, “'Tratados ocultos?, sobre ciertas manifestaciones de la acción concertada no convencional en el marco de las competencias reservadas a los tratados internacionales”, in S. Torres Bernárdez et al., supra n. 36, at 75-IoI.

39 Some years ago, the official publication (BOE) of administrative agreements, including resolutions of Joint Committees, had already been proposed. This was provided in the preliminary draft for the Treaties Act, November 1990, which concerned such matter in Article 19.2. f). If domestic administrative regulations and also international treaties are officially published (BOE), administrative agreements developing treaties must be published as well, thus becoming susceptible of ordinary judiciary control of citizens' rights, such as Social Security rights, therein contained. See A. Fernandez Tomas, La celebración de tratados bilaterales de cooperación por España: una síntesis de la práctica contemporánea (Tirant Lo Blanch, Valencia, 1994), at 123-124.

40 O. Schachter, "Les actes concertés a caracter non conventionnel", in M. Bedjaoui, Droit International. Bilan et Perspectives (Pédone, Paris, I99I), at 277-282; O. Schachter, "The twilight existence of nonbinding international agreements", 7I AJIL (1977), 296-298; M. Virally, 60 AIDI Rapport (1983), 166.

${ }_{4 \mathrm{I}}$ P. M. Eisemannn, "Le gentlemen's agreement comme source du droit international", JDI (1979), 326.

42 M. Ortega Carcelén, "La identificación de las normas jurídicas internacionales convenidas escritas". Doctoral thesis on file at the UA, Madrid (1988), vol. I, at 95; http://hdl.handle.net/10486/11138.

43 Ministry Report, supra n. 4, at 20.

44 That is the case even in the political-military sphere, since the Helsinki Final Act (1975) has been characterised that way. See M. Prévost, "Observations sur la nature juridique de l'Acte Final de la Conférence sur la Securité et la Cooperation en Europe", AFDI (1975), at 129; Russell, "The Helsinki Declaration", AJIL (1976), at 242; however, it has been argued that the Helsinki Final Act "is explicitly considered to create no legally enforceable obligations" (emphasis added) A. Mangas Martín, in M. Díez de Velasco, Instituciones de Derecho Internacional Público ( $18^{\text {th }}$ ed., Tecnos, Madrid, 2013), at 194; despite such character, C. Izquierdo Sans, argues that "some years later, it has served as a basis for the creation of OSCE", so it does have produced some effect. See C. Izquierdo Sans, "Intervención parlamentaria en la celebración de tratados internacionales en España”, 4 REEI (2002), at 45 and footnote 158 .

45 O. Schachter, Les actes concertés, supra n. 40 at 279. 
references ${ }^{48}$ are not to be taken into account although should it not be explicitly formulated. The second problem is more complicated, and I am afraid that the majority of scholars do not share my position.

Both questions are thought provoking. I will first address terminology. Remiro Brotóns is responsible for coining the term "acuerdo no normativo" ("non-normative agreement") within Spanish academia ${ }^{49}$. But he has recently revised this expression for "acuerdos no jurídicos" ("non-legal agreements") so. Obviously, these agreements are not able to create "rules" [or norms] of general application due to its very own nature. They only generate obligation between the parties if they are legal agreements. If that is not the case, they should not create any obligation in the Legal realm. Nevertheless, though it may not be immediately clear, even an agreement of this sort creates commitments or future behaviour patterns $s^{51}$ for the conduct ${ }^{52}$ of the parties. However, in order to enforce this commitment we cannot resort to certain tools provided by Law, which does not mean necessarily mean that it loses its legal character altogether. Is it not possible to concert a legal instrument with the aim of creating non-enforceable obligations? Is it not possible to acknowledge the existence of non-enforceable legal agreements? In my opinion, it is indeed possible, and the very reason for why it makes sense to talk about non-binding agreements ${ }^{53}$-the label chosen by some scholars. Still, once the TOIAA has incorporated the expression "acuerdos internacionales no normativos" (AINN) (lit. non-normative international agreements), the terminological debate becomes irrelevant.

Secondly, regarding its efficacy, it is absurd to establish an agreement that does not generate any future conduct pattern on either side. What could its purpose even be? However, there could be some logic in concluding an agreement trusting (in good faith) upon the parties' will of compliance. Such an agreement creates expectations of voluntary compliance, but parties agree that they cannot legally demand compliance from each other. That way they can avoid consequences deriving from political or budgetary reasons that are hard to justify and which render compliance unfeasible. Thus, a potential

${ }_{46}$ Ministry of Foreign Affairs, (Circular 3.286, July $1^{\text {th }}$ 2010), processing of non normative agreements. [Unpublished]. It includes, in point III, a series of drafting advice that would enable the Spanish party to claim that an agreement is "not normative", referring to labelling, concluding entities, avoiding compromising final clauses, the "dismantling" of a text avoiding certain organization of articles, etc.

47 MAEC-AECID, La ayuda programática. Guía Técnica para la puesta en marcha de los nuevos instrumentos de cooperación (2008); Annex 3, at 74-82. www.aecid.es/galerias/cooperacion/.../La_ayuda_programatica.pdf. This is a Drafting Guide for a Memorandum of Understanding, resuming the "Guide to joint financing arrangements", from Canada, Denmark, Finland, Ireland, Netherlands, Norway, Sweden and UK.

48 A. Remiro Brotóns includes for the first time the "Io Commandments" that must be followed when drafting this type of document in "De los tratados a los acuerdos no normativos", in La celebración de tratados (1990), supra n. 3, at 47-48. The same position in A. Remiro Brotóns et al., Derecho Internacional (Tirant lo Blanch, Valencia, 2007), at 337-338.

49 A. Remiro Brotóns, Derecho Internacional Público. 2. Derecho de los tratados (Tecnos, Madrid), 1987, at 177.

so A. Remiro Brotóns et al., supra n. 48, at 334. See the literature on non-legal agreements provided in p. 347.

${ }_{51}$ See, e.g., the Joint Statement signed by Spain and East Timor (May 20th, 2002), where both States "agree on establishing diplomatic relations”, quoted in J. González Vega, ¿Tratados ocultos?, supra n. 38, at 82. This author claims that "from the wording of these agreements it follows an unequivocal international legal effectiveness, even though they have never been conventionally processed”.

52 In certain circumstances, the principle of estoppel may be invoked before someone committing an act of this genre.

53 That stands as a literal translation of the label used by scholars such as O. Schachter, The twilight, supra n. 40 and M. M. Gomma, "Non-Binding Agreements in International Law", Liber Amicorum G. Abi-Saab (Nijhoff, The Hague, $200 \mathrm{I})$, at 229. 
breach does not lead to liability ${ }^{54}$ or to the possibility of legal action, because that is precisely what the parties have agreed upon. In this sense, these agreements are not binding. Since they are founded upon good faith, the consequence of contravention would be the loss of the pre-existing confidence between the parties. It could then be argued that they generate obligations of conduct that may not be legally enforced. The key would not be not to generate legal obligations, but to generate obligations whose enforceability may not be contemplated.

At the multilateral levelss, we find what scholars call rules of soft law, i.e., recommendatory resolutions, like most resolutions adopted by the UN General Assembly. Their adoption is ruled by international regulations (the UN Charter, the rules of procedures of the General Assembly), although compliance is not mandatory, which does not exempt addressees from the easy-to-meet "obligation" of examining its content and trying to adapt their conduct accordingly in good faith. This multilateral legal act shows the closest resemblance to non-normative agreements, which could be considered as its bilateral counterpart ${ }^{56}$.

According to the new Spanish Act analysed below (see below “The Circular of 2010"), those acts may be created by agencies competent in the matter, a qualification generously regulated in our Legal System. There are also legal procedures for their processing and registration. In this sense, we cannot say that they are "not legal", since it is undeniable that they are at least regulated by our Domestic Law. But, on the other hand, breach of agreed stipulations does not entail any responsibility. Neither does it allow an enforced arrangement of differences generated therein. Therefore, their legal existence cannot be questioned, at least in our system, despite the fact that they are not binding57.

But what if despite not being binding, the other party fulfils its commitments and we are also willing to fulfil ours? One specific provision in our Act is almost surreal in this respect. The final paragraph in Article 45 states that "in dossiers regarding Memoranda of understanding that involve financial liability, the existence of budgetary funding adequate and sufficient to comply with commitments derived from them must be certified by means of a report of the Ministry of Finance and Public Administrations". Are they not legal instruments producing a payment obligation? Is that

${ }_{54}$ P. M. Eisemann, one of the first scholars commenting on this subject, addresses this issue. See Le gentlemen, supra $\mathrm{n}$. $4 \mathrm{I}$ at $33 \mathrm{I}$.

55 A. Mazuelos Bellido, "Soft Law: ¿mucho ruido y pocas nueces?", REEI (2004), at I5-28, referred to "non legally binding Inter-state agreements"), contains Thierry's interesting opinion considering them as acts which are neither treaties, not ruled by the Law of treaties, even if are to be taken as part of International Law ( at 45); Thierry defends that just as International Law includes the category of recommendations, it also includes "[...] des accords qui n'ont pas les mêmes effets contraignants que les traités internationaux mais doivent être respectés en vertu des exigences de la bonne foi qui président à tous les engagements pris pour le compte des Etats". H. Thierry, "L'évolution du droit international". Cours Général, RCADI (1990), at 74-75.

56 A. Remiro Brotóns et al. (2007), at 347, contains a bibliographical note to the chapter "Qué es -y qué no- un tratado" (What is - and what is not- a treaty) that includes works on soft law and treaties along with literature on nonnormative agreements or non-legal agreements: Del Toro Huerta, "El fenómeno del soft law y las nuevas perspectivas del Derecho internacional", AMDI (2006); W. M. Reisman, "A Hard Look at Soft Law", (1988) Faculty Scholarship Series. Paper 750, available at <http://digitalcommons.law.yale.edu/fss_papers/75>; A. Boyle, "Some Reflections on the Relationship of Treaties and Soft Law, 48 ICQL (1999), 90I-913; F. Francioni “International 'Soft Law': a Contemporary Assessment", Essays R. Jennings (Cambridge, Cambridge University Press, 1996), at 167.

57 Against this idea, A. Mazuelos Bellido supra n. 55, deems them non-legal but still binding; although his work (2004) could not take the new Spanish Act into account. 
payment obligation by any chance based upon Islamic bawala? In any case, it seems that a cautious Administration should provide the corresponding budgetary items, in case they are implemented.

\section{(b) The Circular of 2010.}

Regardless its nature, non-normative agreements have undergone considerable development in Spanish practice, both in Defence ${ }^{58}$ ("collaboration agreements" and "Memoranda of understanding") and international cooperation. This development has been elaborated by bodies and agencies pertaining to the Government as well as by Autonomous Communities (Regions) and local entities ${ }^{59}$, and its "exponential increase" motivated the enactment of a specific Circular by the Ministry of Foreign Affairs in $2010^{60}$.

According to this Circular, the proliferation of these agreements, concluded by all sorts of entities, could put the principle of unity of action abroad into jeopardy. As a result, the Ministry of Foreign Affairs was granted the power to coordinate different agencies within the central administration as well as those of territorial and local administrations by the Technical General Secretary. This Circular establishes the cautious measure of requiring a report from the International Legal Advisory of the Ministry of Foreign Affairs "for their qualification and subsequent processing" (Point II), and that way be certain that the agreement is not a treaty. It is also possible to require a second report from the State Attorney, should the agreement "make reference to issues related with Spanish domestic law and, especially, to competences of the Autonomous Communities". All this is quite reasonable and it might seem "simple" if the negotiating agency pertains to the Central Administration and has powers in the area. But, how are Regions, City Councils, Province Councils, Universities, etc. to be controlled? The best solution is a kind request asking drafters to send the text to the Technical General Secretary. The draft will then be registered in a new software called "Memoranda". Antrobus ${ }^{61}$ would not have done a better job.

The Circular states in the Preamble that these agreements have "an exclusively political nature" and they are not "ruled by International Law ${ }^{62}$ or "any Legal System". Point III concludes: "in essence it is a matter of delineating both the form and content of non-normative agreements from those

$5^{8}$ Ministerio de Defensa, Intervención General de la Defensa, La nueva regulación de los convenios de colaboración y memorandos de entendimiento en el ámbito del Ministerio de Defensa (2005), available electronically at <http://www.portalcultura.mde.es/Galerias/publicaciones/fichero/oror6.pdf>, accessed 28 November 2014.

59 Informes del Ministerio de Asuntos Exteriores y de Cooperación a los Memorandos de Entendimiento de las Comunidades Autónomas con Instituciones Extranjeras, año 2009 (Reports of the Ministry of Foreign Affairs on Memoranda of understanding signed by Autonomous Communities and Foreign Institutions, 2009) (MAEC); Informes del Ministerio de Asuntos Exteriores y de Cooperación a los Memorandos de Entendimiento de las Comunidades Autónomas con Instituciones Extranjeras, años 20I0-20II (Reports of the Ministry of Foreign Affairs on Memoranda of understanding signed by Autonomous Communities and Foreign Institutions, 20I0-20II) (MAEC). The later also includes some agreement signed by Town Halls and Provincial Councils.

60 Circular 3.286, July $19^{\text {th }}$ 2010. [Unpublished].

${ }_{6 \mathrm{I}}$ I am obviously alluding to the character of Lawrence Durrell (Best of Antrobus), Spanish edition, Antrobus, Tusquets, Barcelona, 1986.

${ }_{62}$ Still, at least some basic legal principles should be applicable by sheer logic and resemblance with treaties, such as the principle of bona fides (M. Virally, supra n. 40 at 356); reciprocity, basic rules of pacta sunt servanda, and inadimplenti non est adinplendum, as well as the principle of estoppel. Are non-normative agreements not supposed to be fulfilled? If one party does not comply with their due behaviour can the other one be considered to be "obliged" to comply with theirs? 
agreements that truly constitute an international treaty, for which purpose a final paragraph explicitly stating that the instrument does not produce binding ${ }^{63}$ legal effects in the sphere of International Law may be included". The only basic cautionary measure for maintaining coherence with the constitutional corpus is introduced at the beginning of Point III that reads: "the content of nonnormative agreements may not address matters that require an authorization of the Parliament [Cortes Generales: Congress and Senate] according to Articles 93 and 94.I of the Spanish Constitution”. This is a basic question regarding the parliamentary control of these agreements, which will be analysed below in the last section of this article.

\section{(c) TOIAA contents}

TOIAA regulates NNIA at Title IV (articles 43-48), after providing a definition in Article 2.c. The definition enumerates four necessary elements to qualify a legal act as a NNIA. I. Agreements are defined by what they are not, since they have "an international character" not constitutive of either a treaty or an Administrative International Agreement. 2. They may be concluded by a wide range of subjects, such as: "the State, the Government, bodies, agencies and entities pertaining to the Central Administration, Autonomous Communities and the Cities of Ceuta and Melilla, local entities, public universities and any other subject of Public Law with the appropriate powers". 3. "they contain declarations of intent or establish commitments for action of a political, technical or logistic content". And 4, "they do not constitute sources of international obligations and they are not ruled by International Law".

The most striking feature in this definition, in the context of an act supposedly facing the "exponential increase" or "hectic development" of this sort of agreements, is the generous granting of a capacity of celebrating external agreements to a plurality of subjects that have nothing to do with "foreign affairs", according to a literal interpretation of our Constitution (Article I49.I.3). Nevertheless, it needs to be said that this position is coherent with an even wider list than the one contained in Title I, Articles 4 through 13, Act 2/ 2014 (march 25 ${ }^{\text {th }}$, 20I4) which regulates Foreign Action and Service of the State and establishes a distinction between foreign policy, that corresponds to the Government, and foreign action, that corresponds to almost everyone, to the delight of the Foreign Service.

The Congress Drafting Committee did not accept amendments to Articles 45 through 50, which became Articles 44-49, with no variation after the debate in the Committee on Foreign Affairs in the Congress, and finally, Articles 43-48. We also need to consider Article 53, regulating the conclusion of Memoranda of understanding by Autonomous Communities, the Cities of Ceuta and Melilla and local entities. The content of these six Articles is technically flawed, as they regulate almost nothing and do not address the fundamental issue of limitations of contents (93 and 94.I. of the Spanish Constitution) evoked in The Circular of 2010.

On the contrary, Article 48 does include a provision related to the need to register these agreements contained in the Circular. So, "once it [the NNIA] has been signed" a copy needs to be

\footnotetext{
${ }_{63}$ Emphasis added. See the previous section on terminology.
} 
sent to the Ministry of Foreign Affairs for its inscription at the "administrative register". There is no mention of official publication of these agreements ${ }^{64}$. Besides this, Article 43 briefly states that NNIA are "no sources of international obligations". Article 44 puts some light on the capacity issue, establishing that each subject may celebrate these agreements "in the exercise of their respective powers". The same provision is reiterated in Article 53.I regarding Autonomous Communities, Ceuta y Melilla and local entities. Article 46.I recognizes the "autonomy of signatories to decide procedure", since no processing identical to that of treaties is requires and, not satisfied with that alone, it supposes (paragraph 2) that the Council of Ministers "will note its conclusion (...) whenever their importance makes it advisable, following a joint proposal of the Ministry of Foreign Affairs and the competent Minister according to the subject" (emphasis added). This mean that the Government will have no knowledge of the majority of concluded agreements. The grand finale, however, lies in Article 47 , according to which "reference to the Kingdom of Spain will be included alongside the signatory". This will surely improve the geographical knowledge of the other contracting party, who will be left with no doubts regarding the location of the agency, entity, local entity or any other subject of International Law that might conclude an agreement with them. (So, well, this may be important for town twining!) The combination or Article 45 with Article 53.3 regarding reports (see next section) as a control mechanism for foreign action of Autonomous Communities deserves a special mention.

\section{THE GOVERNMENT'S CONTROL OVER OIAS CONCLUDED BY AUTONOMOUS COMMUNITIES (REGIONS)}

\section{(I) The international dimension of regional powers}

According to an initial mainstream interpretation of the Spanish Constitution, the conclusion of any international agreement used to belong exclusively to the jurisdiction of the State in foreign affairs (I49.I.3 CE). But in a later stage, things changed such that even though the State had the monopoly on treaties making power, Autonomous Communities could also conclude other international agreements (OIA), which are not from treaties. Otherwise, the possibility to exercise powers granted to Regions by the Constitution would be denied whenever this powers had some international dimension. The declaration of nullity of a collaboration communiqué signed by Junta de Galicia (Galicia regional government) and the Kingdom of Denmark in 1984 in Constitutional Court ruling 137/1989 is a good the example of the first stage described above. But even in that decision, one third of the Magistrates agreed on a dissenting vote which stated that a more open conception should prevail before the dominant vision $^{65}$.

This dissenting position became majoritarian in the subsequent case law (especially in the case of the

${ }^{64}$ As long as they are not legally enforceable, official publication is not required either.

${ }_{65}$ Magistrate Díaz Eimil's dissenting vote: "In my opinion the ruling adopted by the majority is based upon a rigid and expansive understanding of the scope title in Article I49.I.3 of the Constitution that leads to depriving Autonomous Communities of any constitutional possibility of performing activities and contacts that even if they have an international dimension do not generate actual and immediate obligations or imply exercising sovereignty, or have an impact on the State's foreign policy and they do no generate any responsibility of the State before other States". 
external representation of the Basque country in Brussels, Constitutional Court ruling 165/1994, F.J. 6), respecting the limits for avoiding interference with the external policy of the State and using almost the same terms employed in the 1989 dissenting vote (the only addition is "that do not imply the exercise of a ius contrahendi"). Finally, our Constitutional Court validates the constitutionality of Article 195 of the Statue of Autonomy of Catalonia (Constitutional Court ruling, 3I/21O, FJ I26) since the notion that the Generalitat (Catalonian Autonomous Government) may "conclude collaboration agreements within the scope of its powers" does not "imply an exercise of a ius contrahendi or the generation of obligations before foreign public authorities, or that it affects the foreign policy of the State or, lastly, the generation of responsibility of the State before foreign States or international or supranational organizations, since those domains are reserved to the State ex art. I49. I. 3" ${ }^{66}$. This case law constitutes the recognition of the capacity of Autonomous Communities to conclude non-normative agreements within the scope of their powers ratione materiae.

\section{(2) The capacity of Autonomous Communities (Regions) to conclude OIAs}

The report written by the Ministry of Foreign Affairs in 2013 for the passing of the preliminary draft assumes that Autonomous Communities may conclude "other international agreements" (a capacity ${ }^{67}$ explicitly recognized in Article 7 TOIAA "within the scope of powers granted to them by the Constitution, the Statues of Autonomy and the rest of the Legal System"). It also assumes that the new Act is going to be "fully respectful" towards that capacity in merely providing "the manner by which the State undertakes the tasks entrusted in the respective Statues of Autonomy (...) as a consequence of the interpretation thereof established by the Constitutional Court according to the exclusive competence reserved to the States in Articles 97 and I49.I.I of the Spanish Constitution, as well as to the corresponding (exclusive) international responsibility of the State ${ }^{68}$ ". Its aim is "the management of the activity of Autonomous Communities in the area of international agreements (...) avoiding any intrusion in subjects that don't correspond to the State"69.

At the same time, the Council of State reminds us that according to constitutional case-law "the establishment of prior controls or authorizations by the State is incompatible with the political autonomy of Autonomous Communities", since that would constitute a mechanism typical of administrative trusteeship. The Council also points out that the external activity of Regions takes place in two different spheres, that corresponding to the EU and that pertaining "to the wide and general [domain] of international relations". In this last sphere, the capacity of Autonomous Communities "is much more limited and must restrict itself to the promotion of their own interests (...) without affecting or interfering with the foreign policy of the State", since the State is granted the power to establish "measures that coordinate foreign activities of Autonomous Regions in order to avoid or remedy potential damages on the management and implementation of the foreign policy,

66 Constitutional Court Ruling 3I/210, FJ I26.

${ }_{67}$ "Inherent faculty to the power's acquis", as it has been rightly pointed in Amendment $\mathrm{n}{ }^{\circ} 98$ of the Basque Parliamentary Group (GPV), Official Gazette of the Congress (BOCG), Congress, Serie A, no 72-2, February I7th 2014 , at 49.

68 Ministry Report, supra n. 4, at 5 .

69 Ibid., at 6. 
which corresponds exclusively to the State" (emphasis added). Having said that, the Council then analyses the conformity between the preliminary draft and the Constitution, then remarks that the control procedure therein established requires two reports, one by the Ministry of Finance (babemus budget) and another one by the Ministry of Foreign Affairs (babemus non-normative international agreement). It is a surveillance system that produces different consequences. Regarding Administrative International Agreements, the legal mechanism is "in accordance with the constitutional system of distribution of competences", because these agreements derive from a former treaty and, considering that only the State can conclude them, "it is [the State's] duty to preventively supervise the terms under which the treaty is to executed" 70 . Nevertheless, regarding non-normative international agreements "the conclusion is not so obvious". The Council reminds that the Constitutional Court held the constitutional validity of a precept in the Catalonian Statue of Autonomy including a general faculty "to conclude agreements within the framework of their competences" ${ }^{71}$. In other words, it may not be presupposed that a non-normative international agreement concluded by a Community affects the foreign policy of the State before its conclusion. But what other reasons could there be to justify an ex ante control?

Within the framework of the Constitution and the Statues of Autonomy of the Autonomous Communities, the interpretive exercise which enables the Government to perform some control of the international activities of those Communities would entail a minimum scope for action. So minimum that it is almost non-existent in the prior phase, while in the posterior phase it would require the State Attorney to contest [appeal] ultra vires acts performed by Communities by means of a conflict of powers lodged before the Constitutional Court. This ex post control has been working since the beginning of our current constitutional regime ${ }^{72}$. The novelty lies at the Government's attempt to build an ex ante control mechanism based upon the sheer power of controlling the nature of such agreements and coordinating them (an impossible mission) in the framework of its foreign policy.

\section{(3) The report of the International Legal Advisory of the Ministry of Foreign Affairs- the need of a minimum control of authenticity}

As we have seen, the established control procedure requires the report of the International Legal Advisory of the Ministry of Foreign Affairs. Such a report is no new element introduced by the TOIAA, since Circular $\mathrm{n}^{\circ}$ 2.95I of July $\mathrm{I}^{\text {st }}$ 1981 established the need of a report of the International Legal Advisory of the Ministry of Foreign Affairs, which precedes the one submitted by the Council of State in the processing of treaties $^{73}$. Likewise, the Order of February $17^{\text {th }} 1992$ (section I) requires that

70 Opinion $808 / 2013$, October $3^{\text {rd }}$, pp. $25-27$.

7 Ibid., at 28 .

72 And it is still working, despite innocence claims of Autonomous Communities. It is justified in cases such as the Fishing Agreement between the Regional Minister of Fishery of the Basque Country and the Minister of Fishery of the Republic of Mauritania (September 2Ist 2003), which was signed while the former was visiting Nuakchott. The agreement was challenged by the State Attorney. Our Constitutional Court found the exclusive jurisdiction of the State under Article I49.I.3 of the Spanish Constitution to be violated (Ruling of the Constitutional Court 198/2013, December $5^{\text {th }}$ ).

73 The TOIAA draft forgot to include the submission of the report of International Legal Advisory of the Ministry of Foreign Affairs in the processing of all international treaties, which had been required up to that moment by Circulars of 1981 and 1992. That is why the SPG proposed Amendment $n^{\circ}$ I2O, pretending to modify Article 17.2: "having considered the 
report as an exigency prior to the expression the of State's consent. Thus, the ILA advises on whether or not the treaty requires a parliamentary ex ante authorization, anticipating the role that corresponds to the State Council.

In this context, however, Article 45 TOIAA might generate some interpretative dissonances since the obligation to report on the draft of each non-normative international agreement is entrusted to the "Legal Service of the respective agency or public body that concludes them" ${ }^{74}$, no doubt brimming with International Law experts. On the contrary, Article $53.3^{75}$ wisely establishes that NNIA drafts "will be submitted to the Ministry of Foreign Affairs before signature in order to obtain the report from the International Legal Advisory regarding its nature, procedure and most adequate instrumentation under International Law. Particularly, it will be established if a draft should be formalised as an international treaty or as an administrative international agreement". Though this is not expressed in the Act, we should assume that either option would depend upon the subject of the agreement, since it does not seem appropriate for a NNIA to cover reserved subjects under Articles 93 and 94.I of the Spanish Constitution, something provided in the Circular of 20IO. In any case, the ILA report is indispensable for purposes of unifying criteria in this matter, which would be impossible if the legal advisor of each agency undertook their own interpretation of the nature of each NNIA passing through his desk.

However, as long as this mechanism might be used as an oblique way to reintroduce a central preventive control, some tension has arisen between the Central Government and the Communities. The intervention of the Basque ${ }^{76}$ and Catalonian ${ }^{77}$ minorities during the parliamentary debate is a

report of the International Legal Advisory regarding the processing of a treaty", which was accepted by the Drafting Committee.

74 UPyD Parliamentary Group wisely proposed the elimination of this first report. Official Gazette of the Congress (BOCG), Congress, Serie A, $n^{\circ} 72-2$, February $\mathrm{I}^{\text {th }}$ 20I4, at 36 . They did not succeed.

75 Applicable only to the 17 Autonomous Communities, Ceuta and Melilla and to "local entities", that is, to the more than 50 Provincial Councils as well as to the thousands of Town Halls operating in Spain. In these cases, a double report would be needed (one submitted by the Legal Service of the involved agency, and one submitted by the International Legal Advisory of the Ministry of Foreign Affairs). While if the signing party of a NNIA is either a Public University, or an "organ, agency or entity pertaining to the Central State Administration", or "any other Public Law entity possessing the corresponding power" (Article 44 TOIAA), there should be no need of a report from the International Legal Advisory of the Ministry of Foreign Affairs. In my opinion, it would have been advisable to require the ILA report only for NNIAs concluded by agencies that could potentially interfere with the foreign affairs policies of the State. That would narrow the entities down to just Autonomous Communities and Ceuta and Melilla. Maybe, when adopting the implementing regulation for the TOIAA, this useless burden could be spared to the ILA.

${ }_{76}$ Mr. Esteban Bravo, MP of the Basque Parliamentary group, in General Amendment $\mathrm{n}^{\mathrm{o}} \mathrm{r}$ : "In the Draft of the Treaties and Other International Agreements Act the State exercises its coordination powers with a centralizing spirit and widening its jurisdiction under I49.I.3 beyond those coordination powers recognised in this matter by the Constitutional Court"; Official Gazette of the Congress (BOCG), Congress, Serie A, $n^{\circ} 72-2$, February $7^{\text {th }} 2014$, at 2; the phrase contained in Amendment $\mathrm{n}^{\circ}$ Ioo to the enacting terms is reiterated seasoned with a poorly founded legal argument: "That is why the regulation of non-normative international agreements is questionable due to intromissions in the jurisdiction of, among other entities, Autonomous Communities, whose relations may not be included within international relations (See Article I49.I.3 Spanish Constitution) strictu sensu, since they lack the nature of subjects of International Law" (Ibid., at 50).

77 The Catalonian Parliamentary Group (Convergencia i Unió), in Amendment $n^{\circ}$ I46, among others, initially defended that NNIA should not be included within the scope of TOIAA, since "it is an imprecise label that introduces considerable confusion and also dilutes the nature of covenant or bond created with its conclusion", Official Gazette of the Congress (BOCG), Serie A, $\mathrm{n}^{\circ}$ 72-2, February 17th 2014, p. 67. Their spokesman (Mr. Xuclá i Costa) added in the debate in the Foreign Affairs Committee of the Congress that: "in the former Foreign Service Act, there was a clear difference between foreign policy, that pertains exclusively to the jurisdiction of the State, and foreign action, whose jurisdiction belongs to 
good example of this controversy. According to them, the Government, whose powers of coordination should not exceed the sheer gathering of information, pretends to be coordinating ${ }^{7}$ but in reality it would be either filtering o approving ex ante the international activities of the Communities ${ }^{79}$. Yet, according to the Government, this control is merely trying to prevent "hidden treaties" presented as OIA, from making their way in "through the back door". We hope that, thanks to reiterated report from the International Legal Advisory of the Ministry of Foreign Affairs, at least some unifying criteria are established regarding the issue of when an international agreement must be "formalised" as a treaty or when it may "informally" survive as non-normative agreement. This would hardly be feasible with a wide range of reports scattered all over public offices.

Autonomous Communities. And else this Act, this Draft tries to include, under a specific title, administrative international agreements as a directive subjected to the control of the Central Government. This implies, honourable MPs, a step backwards in respect of what bad been a sound practice during the last 35 years and it is a partial manifestation, if you will, but still another manifestation of the Government directly undermining the jurisdiction of the Autonomous Communities. The well-defined distinction between foreign policy and foreign action established in the Foreign Service Act tries to be spoilt through an attempt to regain powers with this Act by means of the control mechanisms of non normative administrative international agreements (sic), which the Autonomous Communities bad been babitually concluding with no need of this sort of centralizing control. The Central Government has been resourcing to principles of effectiveness and coordination, but also to the role conferred to the Inter-Ministry Council, which is enabled to have a potential influence, submit opinions and restrain the foreign action of the Autonomous Committees. (...) So, we have several Amendments aimed at eliminating the control over non normative administrative international agreements (sic)"; (emphasis added); Diario de Sesiones del Congreso de los Diputados (Record of Parliamentary Proceedings), $\mathrm{n}^{\circ} 587$, June $\mathrm{II}^{\text {th }}$ de 20I4, at 4.

${ }_{78}$ As Mr. García Margallo, Minister of Foreign Affairs, claimed when presenting the draft in the Congress, "The Act also creates an Inter-Ministry Committee to facilitate coordination on this Matter in Article 6. This coordination has a horizontal character and it promotes information exchange and coordination among Ministries. It also possesses a vertical character, establishing the way to guarantee the effective implementation of the due cooperation between the Central Government and the Autonomous Communities".

79 "We are returning to the discussion of the Foreign Act, to call it generically, where we insisted, on behalf of our group as well as some other group that we have to identify very clearly what is a foreign action that corresponds to the Autonomous Communities according to their jurisdiction. This does not belong to the realm of foreign relations, but to their domestic powers that are projected outside the boundaries of the State territory. Foreign policy is a different matter. Foreign policy does pertain to the reserved jurisdiction of the State and it may not be affected or hindered by actions undertaken by the Autonomous Communities. Nevertheless, the Government is here overprotecting itself and is trying to control spheres that do not belong to it. Regarding this issue, I would highlight Amendment 85 to Article 4.2 in which it is clearly expressed that the Ministry of Foreign Affairs will undertake, in its relations with the rest of public offices, advisory and coordination tasks as well as other functions granted in this Act. We are not against this notion as along as this remark is added: that aim at avoiding or remedying potential damages on the direction and execution of the Government's foreign policy in this area, that is, the foreign policy of the Government, not in the area of foreign action, where there should be liberty for the Autonomous Communities. We are afraid that the current wording does not grant this liberty". (Emphasis added). Mr. Esteban Bravo (BPG). Record of Parliamentary Proceedings (Diario de Sesiones del Congreso), Comisiones, $\mathrm{n}^{\circ} 587$, June $\mathrm{II}^{\mathrm{th}^{\mathrm{th}}}$ 20I4, at 2.

8o Mr. García Margallo, Minister of Foreign Affairs, claimed: "The defendant of the Amendment (BPG) says that the identification of administrative international agreements and the coordination powers of the State cannot go beyond requiring information about their conclusion, excluding any other bierarcbical ascendancy of the State. This statement contradicts the content of the Act. What the Act says is that the State must necessarily intervene in order to qualify the agreement for processing purposes, since it may be an instrument of international law. The purpose, as I have previously explained, is that administrative international agreements and non normative agreements retain their nature and do not serve as a way to sneak in international treaties, in which, exclusive power correspond to State" (emphasis added). 


\section{PARLIAMENTARY CONTROL OF OIA CELEBRATED BY THE GOVERNMENT}

It is well known that the Spanish Constitution provides the necessity for the Government ${ }^{81}$ to require an ex ante parliamentary authorization in order to conclude certain treaties regulated by Articles 93 and 94.I of the Constitution ${ }^{82}$. Whereas that, it would be enough for the Parliament to be informed immediately afterwards for the rest of the cases. Spanish constitutional case law regarding the conclusion and incorporation of treaties is quite scarce, since besides Order II4/199I (see introduction above) and the Borgobello affair ${ }^{83}$, the only relevant constitutional decision is ruling $155 / 2005$, 9th of June $2005^{84}$. Nevertheless, this ruling ${ }^{85}$ has a crucial importance; especially if we take into account that recent practice has done nothing to comply with it. (See below section (2), pp. 8I ff.).

On the other hand, our Constitution, even though it employs the term "covenant" (convenio), just next to the mention of treaties, in different Articles (94.I.b, c, d and e; 94.2; 96.2), it seems to consider it synonymous since there is no mention to any "other international agreement". However, considering the circumstances, the term "covenant" (convenio) may lead to a broad interpretation of Article 94.I of the Constitution according to which other international agreements at the very least require the Parliament to be informed to enable its control. The basis for such reasoning would be the notion that when controlling foreign governmental policies it is the subject rather the form what really matters. So, if the Parliament lacks information, it is impossible to exercise any control on the correctness of the qualification presented by the Government (assisted by the International Legal Advisory of the Ministry of Foreign Affairs). If a legal act were incorrectly qualified as an OIA while in reality being a true international treaty and the Parliament were not properly informed, the dysfunction would only be noticed after its publication of the Official Gazette (BOE). That is if they

8r In this regard, it is closer to the French system and different from the British one.

82 Spanish scholars have thoroughly analysed these problems. See A. Remiro Brotóns, (1987), at II4-I43; Ibid., "Comentario a los arts. 93 y 94 de la Constitución”, in O. Alzaga (ed.), Comentarios a las Leyes Políticas. Constitución española de 1978 (EDERSA, Madrid, 1985) v. VII (2nd ed., 1998), at 506; P. Andrés Sáenz De Santa María, Sistema de Derecho Internacional Público (2nd ed., Aranzadi, Pamplona, 2012), at 617-6I8; M. Díez de Velasco (2013) at 197-199; J. D. González Campos, L. I. Sánchez Rodríguez and P. Andrés Sáenz De Santa María, Curso de Derecho Internacional Público (4th ed. rev., Aranzadi, Pamplona, 2008), at 276-280; C. Gutiérrez Espada, supra n. 4, at 375-377; A. Remiro Brotóns et al. (2007), at 346347 and 4II-4I3; A. Rodríguez Carrión, Lecciones de Derecho Internacional Público (5th ed., Tecnos, Madrid, 2002), at 216-220. Also in this Yearbook, see Izquierdo Sans, C., "Parliamentary Procedure in the Conclusion of International Treaties in Spain”, 5 SYbIL (1997), I-4I, available electronically at <http://www.sybil.es/documents/ARCHIVE/vol5/Izquierdo.pdf>.

83 Constitutional Court ruling I4I/1998, June $29^{\text {th }}$. Considering whether the withdrawal of a reserve "needs or does not need to be officially published in order to have full effect in our Legal System", the CC finds that: "a clause in a treaty (it has already been established that the withdrawal of a reserve counts as a clause) is not incorporated into Spanish Domestic Law if it has not been previously published officially. Spanish courts cannot apply a conventional provision that has not been integrated into our Law, especially if a fundamental right such as liberty is affected".

${ }^{8}$ A. Salinas de Frías, "La reafirmación del necesario control parlamentario de la actividad convencional del ejecutivo. Comentario a la sentencia 155/2005, de 9 de junio, del Tribunal Constitucional”, 57 REDI, (2005), I2I-I44.

${ }_{8}$ It is remarkable due to its prohibition of an ex ante Parliamentary authorization being substitutable by a Decree-Act of the Government later validated by the Parliament (thus eluding due debate). According to F.J. 9: "Ex ante Parliamentary authorizations regulated in Article 94.I of the Constitution correspond to a non-legislative power under the Constitution, so the use of a procedure provided by the Constitution for the exercise of a certain jurisdiction that possesses its own procedure is constitutionally relevant. The question is (...) if the specific jurisdiction exercised by this [organ] has resourced to the procedure constitutionally prescribed for these cases. All in all, the question is whether the Constitution requires a procedure reserve as well as an organic reserve for authorization needed for international commitments, since we are talking about different powers under the Constitution" (emphasis added). 
are published, because non-normative international agreements are just registered. In order to avoid such a scenario every administrative international agreement and all NNIA concluded by the Government must be submitted to the Parliament ${ }^{86}$.

In any case, special attention should be paid to the qualification or OIA regulating subjects reserved under the Constitution, since if a treaty were erroneously qualified as an OIA, the conclusion procedure would be deprived of all due constitutional guarantees. There would no report from the Council of State and no ex ante parliamentary authorization either if the object were matters contained in Articles 93 or 94.I of the Constitution. In any case, if it was not officially published and just registered, an ex post judiciary control would not be possible either. There is a difference here between NNIA (registry) and AIA (publication) regulated by the TOIAA, but unfortunately, the publication of AA "non regulated by International Law" is not provided, leaving these agreements outside the scope the act. There is no legal obligation to have them officially published. Interestingly, may are yet published in case someone needed to invoke them. Either way, it would be necessary that the implementing regulation of the TOIAA corrected this gap and made official publication compulsory for the Administration.

\section{(I) The control of NNIA}

Regarding NNIA concluded by the Government, let us remember that the Circular of 2010 introduced the caution that their content "could not include subjects requiring parliamentary authorization according to Articles 93 and 94.I of the Spanish Constitution”. But nothing similar is to be found in the TOIAA draft. That is why the Socialist Parliamentary Group, the day before the debate in the Parliament Commission on Foreign Affairs, presented a compromise amendment trying to qualify the terms referring to this issue ${ }^{87}$. The key idea would not be to probibit non-normative agreements in these cases, as long as they stand as technical instrument at the service of the foreign affairs of the Government. What matters is, if they regulate reserved matters, they should receive the corresponding ex ante parliamentary authorization just as if they were treaties. So the SPG amendment suggested that "when a non-normative international agreement regulates subjects included in Articles 93 and 94 of the Constitution, the Government must subject such an agreement to an ex ante parliamentary authorization”. This compromise amendment was rejected.

This is not just a theoretical issue. Our parliamentary praxis has seen some interesting interpellations asking why the Hispano-British Declarations on Gibraltar (Lisbon, April $10^{\text {th }} 1980$; Brussels, November $27^{\text {th }}$ 1984), as well as a later London Agreement on the joint use of the airport (1987) had not been subjected to ex ante parliamentary authorization if they generated specific legal obligations (such as gate opening and free transit of people) affecting territorial integrity and

${ }^{86}$ In this trend, the SPG proposed Amendment $n^{\circ}$ II3, which defended the need to add a new section to Article 3.d [d) ter] aiming at "Providing the submission to the Parliament of the rest of treaties, covenants, agreements and administrative international agreements for its knowledge", further explaining that the motivation of the Amendment was to include "all treaties and agreements, even the administrative one, under the obligation of submission to the Parliament". The Amendment was rejected by the Drafting Committee.

87 Compromise Amendment to new Article 47 bis (unpublished). 
fundamental rights established in Title ${ }^{88}$. They seem by all accounts to be camouflaged or hidden treaties. Similar acts could have taken place or be repeated in the future regarding Ceuta, Melilla or the potential responsibilities that Spain still has as a former Administering Authority regarding the territory and population of Western Sahara. Democracy strongly demands parliamentary intervention in such cases.

\section{(2) The control of AIA and of the bailout agreements to rescue Spanish banks}

A rushed classification may be dangerous in the realm of treaties. For example, if one, while reading the Official Gazette (BOE), by mere chance stumbles upon the Memorandum of Understanding on Financial-Sector Policy Conditionality, drafted in Brussels and Madrid by Spain and the European Commission (July $23^{\text {rd }}, 2012$ ), dealing with the bailout of Spanish banks ${ }^{89}$, the first thought that comes to mind is that it is definitely a treaty. This is significant because it regulates a financial ammount of 4I.000 million euros. But if one looks at its designation, even though this might not be a good criterion to determine its legal nature, one may observe that the title serves a generic denomination for the whole category of Non-normative Agreements or MOU and hastily conclude that the instrument salvaging the taxpayers' pocket is a NNIA. Regardless, either option is misleading. Such a memorandum has been qualified by the International Legal Advisory of the Ministry of Foreign Affairs as an "administrative international agreement" ${ }^{\circ}$. That way, due parliamentary control in case it was a treaty is avoided.

This issue has extensively monopolised the debate between the two major Parliamentary Groups in Spain ${ }^{91}$ when discussing both overall amendments and amendments to the enacting terms. Since, even though the Minister is concerned about Autonomous Communities "not sneaking in international treaties, which belong to the exclusive scope of the State, through the back door" (emphasis added) ${ }^{92}$, he does not seem to care that the Government may play the same game with the Parliament and sneak in

88 C. Izquierdo Sans, Gibraltar en la Unión Europea (Tecnos, Madrid, 1996), at 98.

89 Official Gazette (BOE), December $10^{\text {th }} 2012,84.550$.

90 Memorandum of Understanding [between the European Commission and Spain] on Financial Sectorial Policy, Brussels and Madrid, June 23rd 2012 (BOE $n^{\circ}$ 296, December $\mathrm{IO}^{\text {th }}$ 2012). References were made in the Parliamentary discussion between Mr. López Garrido (SPG) and Mrs. Miguélez Pariente (PPG), in which, Mrs. Miguélez told: "you make constant references to this MOU approving the bailout of Spanish banks or financial aid to Spain. The International Legal Advisory of the Ministry qualified this MOU as an administrative international agreement; it was never a non-normative agreement" (emphasis added), Record of Parliamentary Proceedings (Diario de Sesiones del Congreso de los Diputados), Comisiones, $\mathrm{n}^{\mathrm{o}} 587$, June $\mathrm{II}^{\text {th }}$ 2014, pp. 8-Ir. The report of the International Legal Advisory of the Ministry of Foreign Affairs has not been published, but references to the theses therein defended may be found in A. Pastor Palomar, "Tipos de acuerdos internacionales celebrados por España: al hilo del proyecto de ley de tratados y otros acuerdos internacionales de noviembre de 2013", 66 REDI (2014), 331-337.

${ }_{91}$ As the spokesman of the SPG sustained regarding general Amendments: "What may not be further repeated, Minister, is the shameful show that we had to endure when a Memorandum of understanding establishing enormous financial obligations for the State, such the MOU on bank bailouts, that represent a debt of 40.000 million euros for the State (...), has been discussed and approved by the German Bundestag, while this Camera bad no notice at all. This cannot happen again. Therefore this draft has to prevent such a thing from happening ever again”, (emphasis added). Record of Parliamentary Proceedings (Diario de Sesiones del Congreso de los Diputados), Pleno y Diputación Permanente, 20I3, X Legislatura, Núm. 165, Plenary Session $\mathrm{n}^{\mathrm{o}}$ 156, December i2th 2013, available electronically at <http://www.congreso.es/public_oficiales/Lio/CONG/DS/PL/DSCD-Io-PL-I65.PDF>.

92 See supra n. 80. 
through the same door something so cumbersome as a camouflaged treaty entailing a financial obligation worth 41.000 million euros. The thesis defended by the International Legal Advisory and the spokeswoman of the Popular Parliamentary Group in Congress claims that we are facing two administrative agreements formally and materially covered by the Framework Agreement on European Financial Stability Facility (EFSF), subscribed to by the 16 members of the euro zone and the ESFS (June IO ${ }^{\text {th }}$ 2010) ${ }^{93}$. These administrative agreements would be but developing and implementing the aforementioned Framework Agreement. Interestingly, none of these two "administrative agreements" is referred to using that very expression, since the first goes under the title of "Framework Agreement on Financial Assistance between the European Financial Stability Facility and Spain, the FROB and the Central Bank of Spain" (July 24 ${ }^{\text {th }} 2012$ ), and the second as the "Memorandum of Understanding on Financial-Sector Policy Conditionality between Spain and the European Commission" (July $23^{\text {rd }}$ 20I2). It does not require a scheming mind to appreciate a misguiding intention behind those camouflage labels.

The line of reasoning displayed by the International Legal Advisory and the Popular Parliamentary Group may be attacked for three reasons. Firstly, because even if the treaty signed by the 16 countries of the euro zone and the EFSF in 2010 is a framework agreement, not all developing agreements of a framework agreement need to be administrative agreements. They may as well be new international treaties needing parliamentary authorization. Secondly, as it is pointed in the Constitutional Court Ruling STC $155 / 2005$ (June 9th 2005), mutatis mutandis, "the financial dimension of the obligation assumed by the Spanish Treasury Authorities according to these New Agreements renders the ex ante parliamentary authorization unavoidable". Thirdly, the International Legal Advisory itself, in the context of similar agreements established by the other 15 members of the EU for the bailout of Greece (Spain being of the creditors on that occasion), considered that agreement to be a treaty implying financial obligations for the Treasury Authorities (Article 94.I.d Spanish Constitution) and therefore subjecting it to ex ante parliamentary authorization. Let us examine with greater detail these three arguments leading to a "reclassification" of these AIA as treaties.

\section{(a) The relationship between the Framework Agreement and the Development Agreements}

One of the possibilities to speed up the parliamentary processing of treaties that was considered in our first democratic legislatures was to have the Parliament to grant a multiple effect authorization, based upon the alleged existence of a single block formed by the framework agreement and the development agreements. That way, the parliamentary authorization granted for the former would also cover the latter. This formula was present in the preliminary draft to the 1985 Act of Treaties, whose Article Ir.3 stated: "the Parliament [Congress and Senate], as requested by the Government, can extend the authorization granted for the conclusion of a treaty to the development, interpretation and implementation agreements negotiated later by the Government, on such terms as it sees fit". The utility of this first formula - a treaty developing a framework agreement- consists of smoothening parliamentary control so that the authorization initially granted to the framework agreement could

\footnotetext{
93 Official Gazette (BOE), July II ${ }^{\text {th }}$ 20Ir.
} 
spare the Government the need of ex post authorizations regarding its development. Nevertheless, such formula was never implemented. Even if many cooperation agreements were labelled as a "covenant developing a general agreement", such indication did not produce different results regarding its parliamentary procedure, since the Congress required an authorization for every developing tool of a framework agreement whose implementation needed an expenditure, considering the existence of a financial duty for the Spanish Public Treasury (Article 94.I. d Spanish Constitution).

A second formula with a similar aim- an administrative agreement developing a framework agreementconsists in developing framework agreements by means of legal instruments that are not international treaties, but administrative agreements, in this way avoiding the ex ante parliamentary authorization. It is true that Constitutional Court Order II4/1991 abstractly admitted in a laconic and lonely phrase the constitutional conformity of administrative developments of international treaties needing parliamentary authorization. It was, then, thought that the treaty and the administrative agreement had a similar relationship to that existing in domestic Law between an Act and its administrative regulation ${ }^{94}$. However, Constitutional Court Ruling 155/2005 (June $9^{\text {th }}$ 2005) widens and specifies its position regarding a similar case to the contemporary one in which the States engages in an important international financial obligation. This means that even though the Government is generally entitled to use such a "regulatory" procedure, there would be an impediment when the subject regulated by the development agreement is reserved to the Parliament. If the cameras are neither informed nor required for permission, they are not able to perform their authorising duty constitutionally provided. One may even wonder whether legal acts that differ from an international treaty may serve as a valid substitute when Spain is assuming certain international commitments. That is, if an OIA is a suitable tool for the assumption of obligations such as those regulated in Articles 93 and 94.I of the Spanish Constitution. It would be tantamount to defending -in the same fashion as the "procedural reserve" excluding the procedure of Royal Decree Acts for these cases established in the Constitutional Court Ruling 155/2005the advisability of establishing an "instrumental reserve" (towards the general regime of treaties) that would prevent the Government from resorting to OIA to concert agreement on reserved subjects. In this case, the determining reasons wouldn't be mainly formals, but would rather relate to the necessary intervention of another power of the State.

\section{(b) The Constitutional Court Ruling I55/2005}

The Constitutional Court Ruling 155/2005 comes on the heels of a constitutional remedy filed by the SPG against Royal Decree-Act $14 / 1998$ (October $9^{\text {th }}$ ) regulating the accession of Spain to different Agreements of the International Monetary Fund and against Act 13/1999 validating the aforementioned Decree-Act. The IMF had decided to present an amendment (the fourth one) to its establishing treaty and to widen the financial resources of the Fund increasing $45 \%$ the fees paid by every country. The appellant sustained that "Article 94.I d. of the Spanish Constitution includes into the general regime of treaties and particularly, to the need of ex ante parliamentary authorization, every manifestation of the

\footnotetext{
94 Constitutional Court Order II4/I99I, FJ 4.
} 
State consent by means of a treaty whenever it implies "financial obligation for the Public Treasury", adding up to the specific limitations imposed by Article 86.I of the Spanish Constitution on DecreeActs" (emphasis added; Pleas, 3).

These limits are but "the specific application of a basic constitutional principle- all public expenses require authorization of the people's representatives; such a principle needs to coexist with the role played by the Government in international affairs, a balance that tries to be achieved by means of $a$ specific constitutional procedure characterised by the weighing of the respective positions of both the Government and the Parliament and that cannot, under any circumstances, be substituted by some sort of "self-authorization" of the Government" (emphasis added). Mutatis mutandis, what has been established regarding the Royal Decree-Act as a forbidden legal formula for certain subjects and scopes, is fully applicable to administrative agreements that serve as a self-authorization of the Government or its agencies. That is to say, administrative agreements regulating reserved subjects needing parliamentary intervention in order for the Government to express a valid consent would violate the Constitution.

The appellants alleged that such a "special allocation of special drawing rights" meant an increase of 268.5 million euros of special drawing rights for Spain. We would, then, be talking about covenants imposing financial obligations for the Public Treasury that fall within the categories included by the Council of State (Report $\mathrm{n}^{\circ} 46.685$, June $8^{\text {th }}$ 1990) as pertaining to the scope of Article 94.I d. That is, "international instruments that generate active and passive financial transactions for the Public Treasury, may be economic credit or legal credit for monetary obligations". The same idea has been defended by the Council of State (Report 3.936/98/MC/LD, October $8^{\text {th }} 1998$ ) regarding "provisions for which the State's consent requires, under Article 94.I d of the Spanish Constitution, as an ex ante Parliamentary authorization".

The State Attorney, on the contrary, claimed that no new parliamentary authorizations were needed regarding acts carried out by IMF managers developing their constitutive treaty: "thus it may be sustained that we are facing the very development of the constitutive Covenant ratified by Spain in 1958, which provided that the Fund could borrow currency and here we just find a limit for such operations. It may be said that the act of accession to the constitutive Covenant covers the assumption of this commitment which is its development and, therefore, there is no need of a new parliamentary authorization" (Pleas, 8).

Considering such opposing theses, the Constitutional Court states that "the appellants are right when claiming that Article 2 of the Royal Decree-Act refers to international commitments that imply financial obligations for the Public Treasury" (F.J. 6) (...). "Under such circumstances there is no doubt that the Public Treasury is affected, regardless the ex post formalisation carried out by the Central Bank of Spain" (...) "[T]he financial dimension of the obligation that the Spanish Public Treasury assumes with the incorporation of these New Agreements rendered the ex ante Parliamentary authorization inevitable" (F.J. 6) (...). "Constitutionally speaking it is irrelevant whether this commitment is explicitly formalised in a treaty or by the accession to an obligation born from a treaty that makes it possible but not mandatory; what is decisive is that the State commits to a conduct that was not due at all until that very moment" (emphasis added; F.J. 6). The Court continues: "even if it is sometimes problematic to determine if we are facing international commitments that are merely 
developing prior and more general commitments or rather obligations that, because they essentially affect an already committed obligation, require an explicit and specific consent, it has to be said that alteration by mean of amendment of a Covenant already incorporated into the domestic Legal system under Article 96 of the Spanish Constitution, is an operation that can only be assumed under the conditions required for a new commitment" (emphasis added; F. J. 7).

In the light of these rulings, we must stress the fact that our constitutional design provides a balanced participation of these two fundamental powers of State (the executive and the legislative) in the assumption of international financial obligations for the Public Treasury. And, therefore, that compliance with our Constitution may only be attained by means of legal instruments and procedures that properly enable this co-participation and not by procedures (Decree-Act) or instruments (AIA or NNIA) that render this joint intervention impossible, generating self-empowering mechanism for the Government and neglecting the Parliament.

\section{(c) The procedure for Greece's bailout}

Finally, we should consider the qualification granted in 2010 to Greece's bailout agreements: Intercreditor Agreement of May $8^{\text {th }} 2010^{95}$ (Spain was a part of the 15 creditor States of the EU) and Loan Facility Agreement of May $8^{\text {th }} 2010$ (signed by 14 member States of the EU and KFW as agent of Germany as one party and Greece and the Central Bank of Greece as agent to the borrower as the other $^{96}$. Both agreements were processed as international treaties in the Spanish Parliamentary IX ${ }^{\text {th }}$ Legislature97 ("and not as contracts, despite a clause subjecting non-contractual obligations to English law and even domestic law entities took part in the Loan Facility Agreement), since "they imply financial obligations for the Public Treasury and affect matters requiring Parliamentary law in Spain ${ }^{98 ”}$.

So when Spain acts as one of the 15 creditor States, agreements related to this loan before Greece are processed as international treaties and due ex ante parliamentary authorization (94.I. $\mathrm{d} \& \mathrm{e}$ ) is demanded. On the other hand, when Spain is the debtor, agreements generated from that huge passive credit are processed as administrative agreements and no Parliamentary authorization is required. The contradiction with constitutional aims is shockingly blatant because, obviously, Spain assumes more "financial obligations" (as well as others obligations of a different nature) when acting as a debtor and accepts quite harsh conditions for an enormous loan, however not when acting as a creditor. Such a flagrant violation of the Constitution should have been questioned, so as to challenge both development agreements before the Constitutional Court as an unconstitutionality action, which was possible due to their publication in the Official Gazette (Article 3I LOTC). Unfortunately, Article 33.2 LOTC provides a three months delay to the challenge, which is already passed.

95 Agreement of May 8th 2010 (Official Gazette [BOE] II7, May I3th 2010).

96 Agreement of May 8th 2010 (Official Gazette [BOE] II7, May I3th 2010).

97 Cortes Generales, Record of Parliamentary Proceedings, Diario de Sesiones del Congreso de los Diputados, Pleno y Diputación Permanente, 2010, IX Legislatura, núm 209, December 2th 2010, at 16-18.

98 A. Pastor Palomar, (2014) supra n. 90, at 332. 
It is true that within the legal web created for Greece's bailout there are two agreements, whereas there are three in the case of the Spanish banks, the first one being a generic framework agreement. But, as we have seen (see section 4.2.I. above), this does not mean that agreements developing that framework agreement may not be new treaties requiring parliamentary authorization. This second authorization would fully comply with the constitutional rationale, since financial matters are not included in the framework agreement, but in the development agreements. And it is precisely the financial content of the agreement, and not its formal presentation, what must be supervised by the Parliament.

\section{CONCLUSIONS}

The new Spanish Act introduces two categories not accounted for in our constitutional framework which may be the source of some issues regarding Parliamentary control and, possibly control of constitutionality. With respect to Administrative International Agreements (AIA), the TOIAA should have been more accurate in its definitions, made reference to the limitations of use derived from Constitutional case law, and included within its scope those administrative agreements "not regulated by International Law" as well. As for Memoranda of understanding or Non-normative International Agreements (NNIA), provisions contained in the Circular of 2010 were more incisive than those established in the TOIAA regarding their compliance with the Constitution.

What matters more to the Government are to preventively direct the international activities of the Autonomous Communities carried out using techniques other than treaties. On the contrary, it does not seem to be concerned with the elision of Parliamentary control. Nevertheless, more important than avoiding the signing of a "fisheries agreement" while a Regional Minister is visiting an African country, is to prevent agreements referring to the bailout of Spanish banks from being "sneaked in through the back door". Parliamentary control is neglected when such agreements are qualified as "administrative agreements" even if they contain financial obligations for the Public Treasury worth 4I.000 million euros. Unfortunately, provisions to prevent a similar event from happening again have not been included in the new Act.

The situation resembles a scene from a Spanish comedy from the XVII ${ }^{\text {th }}$ century, in which characters continually chase each other all through the play, only to end up greeting the public on the stage together. The Government chases the Autonomous Communities and is chased by the MPs of the opposition during a law-making procedure that should have been more incisive and accurate. If 50 members of either the Congress of the Senate should dare to bring an action of unconstitutionality against the banks bailout agreements, it should be possible that our Constitutional Court may rule the unconstitutionality of the instruments employed and then some Articles in the TOIAA will have to be modified. But our European creditors should not worry. Even if the Government and the honourable MPs lack soundness, we citizens pay punctually. We are not called taxpayers for no reason. 